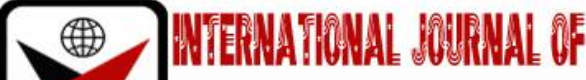

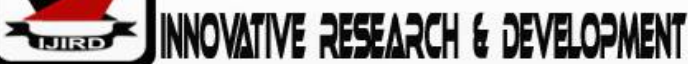

ISSN 2278 - 0211 (Online)

\section{The Role of Occupational Safety and Health Management System on Sport Development in South-West \\ Universities, Nigeria}

Fagbe Tubosun
Principal HSEQ Consultant, Advocacy for Literacy Unity,
Peace \& Economic Advancement Foundation, Lagos, Nigeria
Folorunso-Ako Oladimeji
Lecturer, Department of Sports and Students Activities,
Babcock University, Nigeria
Dr. Fagbe Abimbola 0.
Senior Lecturer, Department of Information Resource Management/Head EAH Library,
Babcock University, Ilisan-Remo, Nigeria

\begin{abstract}
:
The safety and wellbeing of sportsmen of school age group has being an increasing worry for parents, guardians, school's management, public, government and sport administrators. The possibility of building patriotic men and women that may enhance the development of Nigerian sporting sector without considering their safety, wellbeing and strategy for the management of sport associated risks may be slim. Occupational Health and Safety Management System is currently a multidisciplinary field the global community is seriously promoting due to its usefulness, though, with some noted implementation challenges in the educational and sporting sector. Therefore, this paper investigated the role of Occupational Safety and Health Management System (OSHMS) on sport development in Nigerian universities. The study was focused on establishment of documented OSHMS in selected universities, appraised the risk assessed, incidents reports from sports-based activities as well as investigation process, post incident risk management plans, sportsmen awareness and motivational indices. The study was based on primary and secondary data with primary data obtained by means of survey on the stakeholders within the selected universities sport centres and facilities while the secondary data were from the documented records from the sport units of the institutions. Making use of a research review and an extensive interviewing programme, the paper draws several conclusions. The findings established that OHSMS documentation is lacking in all the universities and there were no evidence of risk assessment register covering sport risks, neither were there structured record of sports incident reports and post-incident insurance coverage. The result from the study revealed that establishment of OSHMS and suitable sport risk management insurance by the universities could improve participation of more sports enthusiasts that may possibly result in the development Nigerian sporting sector. Hence recommendations were proffered.
\end{abstract}

Keywords: Health management system, occupational safety, sport, sport development, university

\section{Introduction}

Negligence resulting in injury of sportsmen and spectators has been established as the greatest source of litigation against organizations that provide sport or recreational opportunities across the globe (Van de Smissen 2007). In University Sport cycle, sport administrators are mostly direct employees and in direct contact with students that engage in sporting activities. Therefore, the employment status of the sport administrators may likely induce negligence of care to the sport participants (Cotton 2007, Dougherty 2010). The arising need for sport administrators who work directly with the sports participants to be familiar with sport risks and know how to reduce the possibility of injury to athletes is necessary via adequate knowledge on Occupational Safety and Health (OSH) Management System.

Occupational Safety and Health is an interdisciplinary field that involves the protection, safety, wellness and welfare of stakeholders in a working environment (Kalejaiye 2013). The working environment may be of diverse nature such as factories, construction sites, educational institutions, hospital, stadia and body fitness business outfit. In the context of this research, the workplace is the sport division of universities in South-West region of Nigeria. OSH deals with the process of enhancing safer people and safer workplace by formulating program that identifies hazards and associated risks with necessary mitigating factors HSG 65 (1998) as cited in Fagbe (2009). In achieving the objective of OHS, sets of documented rules as provisional resource and guideline for stakeholders' utilisation are necessary, this set of rules culled 
from the nation's OSH Regulations Umeokafor, Isaac, Jones and Umeadi (2014) and ILO Convention as ratified and domesticated are deployed for the actualisation of OSH management System in workplaces. The university is a tertiary research-based institution where aspiring scholars are nurtured into responsible future leaders in all fields of life including sport. Therefore, the university was chosen as the most viable workplace for the study due to the population of students, multi-faceted activities, diverse professional practices in various fields of endeavour and the cosmopolitan nature of the environment that can be referred to as 'universe city' with possibility of self-sustainability. Currently Nigeria has one hundred and seventy-four (174) universities comprising of forty-three (43) owned by Federal Government, fiftytwo (52) by State Government and Seventy-Nine (79) by private entities. Fifty (50) among the nation's universities are situated in the South Western part of Nigeria comprising of Lagos, Ogun, Ondo, Oyo, Osun and Ekiti State. Nigerian Universities Commission (NUC) December 2019

\section{OHSMS and Employers' Responsibilities}

Having identified the university as the workplace in this research, the founders and the management of the universities are thus the employers, therefore, these employers are the Federal Government, State Government and the Private entities that invested into the university education. OHS Policy formulation and implementation Olatubi \& Olatubi (2017), opined as essential role of government in ensuring safe working environment. This opinion is commendable but has a set limitation and may not be in tandem with ILO Convention on role of employers in OSHMS. Therefore, policy formulation is not restricted to government alone but to all categories of employers in enhancing OSH in their domain. Regardless of who the employer may be, OSH has some basic responsibilities the employers must meet in satisfying OSH requirement of reasonably practicable, reasonably practicable and absolute duties Fagbe (2009). These responsibilities are:

- Introduction of measures that may affect corporate Health and Safety management system.

- Development and authorisation of OSH policy

- Establishment of Risk Assessment process

- Appointing and nomination of competent persons for the implementation of OSH management system

- Establishment of emergency management plan and procedures

- Planning and organization of Health and Safety training.

- Managing Health and Safety consequences whenever new technologies are introduced.

- $\quad$ Funding of Health and Safety programs.

- Dissemination of OSH information to stakeholders

- Consultation of stakeholders on OSHMS development

- Provision of suitable personal protective equipment (PPEs) to workers and third parties that may be exposed to safety and health risks while at work.

- $\quad$ Organise and manage safety and health process in maintaining, controlling, promoting, communicating and in securing competence.

\section{Concept of Sports for Development}

Sports are activities involving competition between two or more people Bendre and Mardhekar, V. (2018); Ajisafe (2009); Mangan 2011. It can also be described based on Olympic context as a game of events, an institutionalised game, social institution and social system. Coakley (1982) as cited by Olanipekun et al (2017). According to Daniel (2015) sports involve activities that individual engages in for different reasons which include; winning of medals, physical fitness, recreation and entertainment. As a form of competition, sports activities give individuals the opportunities to compete against each other and win medals while as a form of keeping and maintaining physical fitness. Sports activities afford people the opportunity of training on desirables weight and fitness level, as form of recreation, people engage in sports activities to re-energize the body and mind after work in order to be able to meet daily demands of life, and for entertainment as many people find watching sports activities enjoyable. Daniel (2015) further asserted that sports activities are usually governed by a set of rules, which serve to ensure fair competition, and consistent adjudication of the winner. Sports involve organized physical activities governed by rules which have values that can be applied to everyday living; therefore, there is need for proper management in order to ensure success. Orunaboka and Nwachukwu (2012) opined that school administrator and educational authorities have realized the benefits accruing from participation in sports programmes and they have not hesitated in including sporting activities (physical education) in their curriculum as a part of the learning experiences offered to the students.

Nhamo and Magonde (2014) carried out a research in Zimbabwe titled, The founding principles of Sport for Development programmes in Zimbabwe and challenges impeding effective programme implementation in which it was opined that, understanding the concept of sport for development (SFD) requires a good understanding of two basic underlying concepts "Development" and "Sport" and how effective the combination and interplay of the two can be used as a tool to enhance human and social development. Furthermore, research has shown that, development through sport is an emergent area of importance in both academic and practical settings, and is seen as a vehicle to facilitate sustainable social and economic improvement in regions of the world targeted (MacIntosh, Spence, \& McDonald n.d.). Four major types of sports were recognised by Ojeme \& Uti (1996) based on Adetunji, and Akindutire (2017) are: outdoor sports, indoor sports, physical development and mental development sports. The benefit of sports in nation building cannot be overemphasised as instrument of unity and peace among various ethnics, religion, race and class. Sports assist in the alteration of some induced ailment and in overcoming emotional stress and depression Ajisafe (2009). Babalola (2010) 
affirmed that sports boost relationship, friendship, self-esteem, teamwork with others. Sport was also discovered as boosting agent for health, body system, educational standard and knowledge (Bucher \& Thaxton (1981). Leadership skills through captainship of team with opportunity of serving as role model to other are attributes of engaging in sporting activities. Sports, the medical practitioners and those in counselling established as good for minds, body and spirit (Adedeji 1985; Ajisafe 2009). Sport as an agent of positive trait development assist sportsmen in goal setting, time management, dedication, perseverance, problem solving and in enhancing relationship management skills (Adetunji, \& Akindutire 2017). Engagement in sports prevents engagement of youths in drugs, smoking and alcohol that may have negative impacts on their health as opined by Payne (1990); Waddington and Smith (2013). Academic excellence and sociability Buneman (2014) linked with sports. Team sports unites Nigerians during competitions with foreign nations as their only aspiration is collective success for the 'Nigerian Team'.

\section{Concept of Sport Safety in University}

Van de Smissen (2007) identified negligence as one of the principal factors for injuries driven litigations against organisations that provide sport or recreational services. Therefore, injuries from sports are possible sources of loss of revenue that may be accrued on treatment, man-hours, corporate productivity and decline in the nation's gross domestic product. Safety in sports is necessary for the protection of the sporting environment against pollution, and environmental hazards. It is useful in achieving safer people, safer workplace via formulation and establishment of documented sets of rules and standards that may be utilised in the identification, prevention, control and management of risks that may affect sportsmen and other stakeholders. Sport Safety serves as morale boosters while lack of OSHMS may be de-motivational tools against interested sportsmen. Documentation, implementation and enforcement of OSH in sport administration will assist stakeholders in achieving optimum benefits of sport through the reduction and elimination of sport risks. According to Surujlal and Singh (2010) from a research conducted in South-Africa on Risk management practices of high school sport coaches and administrators, it was established that several dimensions and individual safety factors were not adequately addressed by relevant personnel, and certain basic minimum requirements were not met. These findings support previous reports by researchers that coaches and administrators are not adequately aware of, or do not fully appreciate the implications of their legal liability relative to sports activities at schools.

\section{Identification and Management of Sport Risks}

Risk identification and management are acts that are learnt from very tender age and utilised throughout the entire period of man's existence Spikket \& Brown (2006) in Fagbe (2009). Risk identification was established as applicable to engineering, manufacturing, marketing, education, sports and all other human endeavours Fagbe (2009)

\section{Typical examples of Sport risks}

- Swimming pool walls and surface collapse

- Drowning of swimming pool users

- Risk of exhaustion and oxygen depletion on athletes

- Risk of heart failure

- $\quad$ Risk of being hit by javelin

- Discuss routing risks

- Lightning strike

- Electric shocks and electrocution

- Dislocations and bone fracture

- Working at height with risk of falling from height.

- Poor lighting with risk of impairment and sight problem.

- $\quad$ Slip, trip and fall as well as collision and overcrowding.

- Fire and explosion inducing first to third degree burns.

- Risk of dust from sporting activities

- Road Traffic Accident and crushing from sport related travels.

- $\quad$ Platform and stage collapse from structural failure and overcrowding

\section{Key Issues Affecting OSHMS in the Administration of Sport in Nigerian Universities}

Twelve key issues were identified by Umeokafor, Isaac, Jones and Umeadi (2014) as necessary factors in enforcing Occupational Safety and Health Management System on corporate organisations in Nigeria. This research established some of the critical factors that may be responsible for the lack of documented OSHMS that can be deployed for the administration of sporting activities in all the universities that were covered. The listed key issues by Umeokafor, Isaac, Jones and Umeadi (2014) as well as other identified factors are:

- Lack of competent OHS personnel in the university employment and in government regulatory agencies. Ezenwa (2001), Okojie (2010) and Diugwu et al (2012)

- Political influence from the founders of the institutions and Government. Idubor \& Osiamoje (2013)

- Absence of inadequate penalty on erring institutions that breached OSH Regulations, Okojie (2010)

- Delay in legal process via challenges from the nation's Judiciary system that discourages people from approaching courts on OSH matters. Idubor \& Osiamoje (2013)

- $\quad$ Bribery and Corruption activities hindering enforcement of rights and standard. Onyeozili (2005) 
- Shortage or lack of fund as well as non-appropriation or fund for OSHMS by the university management as well as by government in funding enforcement due to perceived lean purse. Ezenwa (1997), Ezenwa (2001) and Rantanen (2005)

- Inadequacy of national laws on Occupational Safety and Health especially lack of specific mentioning of sport in the existing Factories Act and the non-signing into Law the National Occupational Safety and Health Bill 2012 by the Federal Government. Diugwu et al (2012)

- Lack of government commitment in the implementation and enforcement of Occupational Safety \& Health regulations in the country. Omojokun (2013), Rantanen (2005) and Makhonge (2005)

- Insecurity of personnel in expressing their displeasure with OSH challenges due to fear of jobs lost in a troubled economy with paucity of employment

- Lack of access to adequate information on OSH by management, employee and stakeholders in sporting activities

- Technology and economic growth challenge

- Culture of uncaring attitude towards OSH matters

- Documented evidence of special Group or individual Insurance cover for the university representatives in sporting activities by the university's management was established not to be in existence by majority of the universities sport administrators.

- Bulk of treatment of injuries incurred by sport enthusiasts was established to be catered for by the victims and their family members, therefore hindering commitment to sporting activities by majority of the sportsmen.

\section{Methods}

The research design for this study employed a descriptive survey method. The target population of this study included all the sport administrators from fifty (50) universities in South-West, Nigeria. The sample size included one hundred (100) randomly selected sport administrators from the target Universities. Furthermore two (2) sport administrators were selected from each of the universities. This was to allow the researchers gathered enough information. The researchers employed the interview method. Information was sourced via visitation to some of the universities for physical assessment as well as via telephone calls and WhatsApp video calls with the aid of structured verbal discussion.

\section{Finding}

\subsection{From the Investigation, Findings Gathered from Sport Administrators Showed That}

- None of the selected universities under review has any OSHMS management approved documented policy

- Documented evidence of valid policy statement on sport and safety by any of the universities were not available. Therefore, indicating lack of top management commitment towards sport safety

- Lack of documented evidence of risk assessment on sport and some other serious hazardous activities in the university were discovered

- Evidence of installation and maintenance of basic safety signs and signals in most of the institution's sport facilities were not available as at time of the research.

- Record of safety induction and periodic safety training records of employees and students participating in sport activities are not available as at the time of investigation

- Evidence of maintaining incident logbook, investigation report, corrective action register and close-out register for sport related activities were not available.

- Documented evidence on audit of sport facilities and equipment in verifying compliance with minimum sport safety standards were not available as indicated by respondents.

- Journey management system covering sportsmen participating in sporting activities outside the campus was not available as indicated by respondents.

- Record of impromptu test of sportsmen for alcohol consumption and some basic medical checks prior to commencement of sporting activities were established not to be in practice during the research period

\section{Conclusion and Recommendations}

Considering the importance of OSHMS on safety and wellness of sportsmen as well as overwhelming discovery of several challenges and some inadequacies on national OSH legislation, implementation default, enforcement somersault that may have embolden the institutions' top managers against the implementation of OSHMS in their domain. Failure of employers in fulfilling their basic obligations on OSHMS as stated by Umeokafor, Isaac, Jones and Umeadi (2014) and established by this research as valid factors in the enhancement of sport development in Nigerian Universities. Therefore, the research suggests formulation of appropriate trainings for top managers to enable them acquire the necessary skill sets that may enhance their contributions towards OSH development, implementation and enforcement in curtailing OSH risks and incidents. Following the above-mentioned findings, the following recommendations are proffered:

- University Management must as a matter of urgency develop appropriate policy in regards to OSHMS that supports sport development in Nigeria Universities.

- University Management must formulate standards and regulations that support sporting activities in universities and the nation at large. 
- Sport officials and administrators in Nigerian universities must as a matter of importance acquire needed perquisites that can place them at par with their counterparts in the developed world

- Sport administrators must be certified OSHMS members in order for them to be familiar with HSE requirements

- Sport participants must be well trained and given required OSHMS information in order to guide against incidents.

- University management and sport administrators must put in place rules and regulations in regards to substance and alcohol consumption.

- Government should as matter of priority develop practicable blueprint on sport safety and empower the Nigerian Universities Commission on enforcing it as part of requirement for accreditation.

\section{References}

i. Abubakar, U. (2015). An overview of the occupational safety and health systems of Nigeria, UK, USA, Australia and China: Nigeria being the reference case study. American Journal of Educational Research, 3(11), 1350-1358.

ii. Adedeji, J. A. (1985). The teaching of physical and health education. Ibadan: West Book Publishers Limited.

iii. Adegun, J. A., Alebiosu, E. O., \& Ajayi-Vincent, O. B. (2017). The Influence of Healthful School Environment and Academic Performance of Primary School Pupils in Southwest Nigeria. International Journal of Health and Pharmaceutical Research, 3(1), 1-6.

iv. Adetunji, O. J., \& Akindutire, I. O. (2017). Benefits of Participation in Sport to the Youth. IOSR Journal of Sports and Physical Education (IOSR-JSPE) 4(1), 30-34 www.iosrjournals.org

v. African Newsletter on Occupational Health and Safety, 2005. Vol. 15 (2), pp 32-33

vi. Ahasan, M. R., \& Partanen, T. (2001). Occupational health and safety in the least developed countries-a simple case of neglect. Journal of epidemiology, 11(2), 74-80.

vii. Ajisafe, M. O. (2009). The role of sport in a developing country. Benin: Headmark.

viii. Akindutire, I. O., \& Olanipekun, J. A. (2017). Sedentary Life-Style as Inhibition to Good Quality of Life and Longevity. Journal of Education and Practice, 8(13), 39-43.

ix. Babalola, J. F. (2010). Handbook of practical physical education. Ibadan: O.B. F. International Press.

x. Bendre, V., \& Mardhekar, V. (2018). Impact of Social Self-efficacy on Personal Growth of Adolescents Active in Sports. Journal of Psychosocial Research, 13(2).

xi. $\quad$ Bucher, C. A., \& Thaxton, N. A. (1981). Physical education and sport: Change and challenge. Mosby.

xii. Buneman, F. H. (2014). Intramural sports: A test and study guide. Wm. C. brown Company.

xiii. Coakley, J. J. (1982). Sport and society: Issues and controversies. St Louis: The Mosby Company.

xiv. Cotton, D. J. (2007). Which parties are liable? In D. J. Cotton \& J. T. Wolohan (Eds.) Law for recreation and sport managers (4th Ed.). (pp. 46-57). Dubuque, IA: Kendall Hunt.

$x v$. Daniel, A. (2015). Sports Management Practices in Tertiary Institutions in Taraba State, Nigeria. A Dissertation

xvi. Diugwu, I. A., Baba, D. L., \& Egila, A. E. (2012). Effective regulation and level of awareness: An expose of the Nigeria's construction industry. Open Journal of Safety Science and Technology, 2(04), 140.

xvii. Dougherty IV, N. J. (1987). Legal responsibility for safety in physical education and sport. Principles of safety in physical education and sport, 15-22.

xviii. Dougherty, N. J. (2010). Legal responsibility for safety in physical education and sport. In N. J. Dougherty (Ed.), Principles of safety in physical education and sport (4th ed., pp. 19-28). Reston, VA: American Alliance for Health, Physical Education, Recreation, and Dance.

xix. Ezenwa, A. O. (2001). A study of fatal injuries in Nigerian factories. Occupational medicine, 51(8), 485-489.

xx. Fagbe, T. (2009). The Implication of Poor Funding on HSE Policy Implementation in the Nigeria Oil Exploration Industry. In Nigeria Annual International Conference and Exhibition. Society of Petroleum Engineers.

xxi. Gallagher, C., Underhill, E., \& Rimmer, M. (2003). Occupational safety and health management systems in Australia: barriers to success. Policy and Practice in Health and Safety, 1(2), 67-81.

xxii. Idowu, M. I., \& Iyabo, V. O. (2017). Ensuring a Safe Working Environment in Nigeria: Reality or Myth. American Journal of Environmental and Resource Economics, 2(3), 107-115.

xxiii. Idubor, E. E., \& Oisamoje, M. D. (2013). An exploration of health and safety management issues in Nigeria's effort to industrialize. European Scientific Journal, 9(12).

xxiv. International Labour Organisation (2016), Nigeria Country Profile on Occupational Safety and Health. www.ilo.org xxv. Kajang, Y. G. (2011). The Use of Modern Methods and Materials as a Basis for the Production of Functional Health Educators for Primary Schools in Nigeria.

xxvi. Kalejaiye, P. O. (2013). Occupational health and safety: Issues, challenges and compensation in Nigeria. Peak Journal of Public Health and Management, 1(2), 16-23.

xxvii. Kim, Y., Park, J., \& Park, M. (2016). Creating a culture of prevention in occupational safety and health practice. Safety and health at work, 7(2), 89-96.

xxviii. MacIntosh, E., Spence, K., \& McDonald, M. (n.d.). Exploring Development through Sport Initiatives: Sharing a Research Program within the Commonwealth Games Association of Canada.

xxix. Makhonge, P. W. (2005). Challenges of development in labour inspection systems. African Newsletter on Occupational Health and Safety, 15(2), 32.

xxx. Mangan, J. A. (2011). Preface: new agendas and new questions for the history of sport. The International Journal of the History of Sport, 28(8-9), 1087-1088. 
xxxi. Nhamo, E., \& Magonde, S. (2014). The founding principles of 'sport for development' programmes in Zimbabwe and challenges impeding effective programme implementation. Journal of Sports and Physical Education, I (5), 2328.

xxxii. Nigerian University Commission (NUC) (Dec 2019), List of approved universities in Nigeria, sourced via www.nuc.edu.ng on $22^{\text {nd }}$ December, 2019

xxxiii. Ogundipe, K. E., Ogunde, A., Olaniran, H. F., Ajao, A. M., Ogunbayo, B. F., \& Ogundipe, J. A. (2018). Missing gaps in safety education and practices: academia perspectives. International Journal of Civil Engineering and Technology (IJCIET), 9(1), 273-289.

xxxiv. Ojeme, E. O. (1985). Problems in the development of sports in Nigerian universities. International Review for the Sociology of Sport, 20(3), 189-202.

xxxv. Okafor, C. (2013). Occupational Health, Safety and Environment (HSE) trend in Nigeria.

xxxvi. Okojie, O. (2010). Systems for reporting occupational diseases in Nigeria. African newsletter on occupational health and safety, 20(3), 51-53.

xxxvii. Okolie, K. C., \& Okoye, P. U. (2012). Assessment of national culture dimensions and construction health and safety climate in Nigeria. Science Journal of Environmental Engineering Research, 2012.

xxxviii. $\quad$ Okoro, Z. G., Nayawo, Z. M., Mohammed, M. A., \& Musa, B. (2016). Factors Influencing the Motivation of Sports Coaches in the Organization and Management of Sports Competition in Owerri Municipal Council of Imo State. American Journal of Sports Science, 4(2), 38-42.

xxxix. Omojokun, J. (2013). Regulation and enforcement of legislation on food safety in Nigeria. Mycotoxin and Food Safety in Developing Countries, 251-268.

xl. Onyeozili, E. C. (2005). Obstacles to effective policing in Nigeria. African Journal of Criminology and Justice Studies: AJCJS, 1(1), 32.

xli. Orunaboka, T. T., \& Nwachukwu, E. A. (2012). Management of physical education facilities, equipment and supplies in secondary schools in Nigeria: Issues and challenges. Journal of education and practice, 3(3), 43-47.

xlii. Sanni, D. M., Ede, C., \& Fashina, A. A. (2018). A study on the effects of inadequate sport equipment and facilities on sports development and academic performance in primary schools: a case study of Bwari area council of AbujaNigeria.

xliii. Shehu, J. (2000). Sport in Higher Education: an assessment of the implementation of the national sports development policy in Nigerian universities. Assessment \& Evaluation in Higher Education, 25(1), 39-50.

xliv. Surujlal, J., \& Singh, C. (2010). Risk management practices of high school sport coaches and administrators. South African journal for research in sport, physical education and recreation, 32(1), 107-119.

xlv. Otinwa, G. O. (2012). African perspectives on physical education and sports. The Global Journal of Health and Physical Education Pedagogy, 1(1), 42-49.

xlvi. Payne, S. D. (Ed.). (1990). Medicine, sport and the law. Oxford: Blackwell Scientific Publications.

xlvii. Udoh, U. P., Atser, J., \& Peterside, B. (n.d) Performance of Recreational Facilities in the University of Uyo Staff Club. Journal of environmental Design (JED) is published bi-annually by the Faculty of Environmental Studies, University of Uyo, Akwa Ibom State, Nigeria. 133.

xlviii. Umeokafor, N. I., Umeadi, B., Jones, K., \& Igwegbe, O. (2014). Compliance with occupational safety and health regulations in Nigeria's Public Regulatory Entity: A Call for Attention. International Journal of Scientific and Research Publications, 4(5), 302-304.

xlix. Umeokafor, N., \& Isaac, D. (2015). A framework for analysing the determinants of health and safety self-regulation in the construction industry.

l. Umeokafor, N., Evaggelinos, K., Lundy, S., Isaac, D., Allan, S., Igwegbe, O., \& Umeadi, B. (2014). The pattern of occupational accidents, injuries, accident causal factors and intervention in Nigerian factories. Developing country studies, 4(15), 119-127.

li. Umeokafor, N., Isaac, D., Jones, K., \& Umeadi, B. (2014). Enforcement of occupational safety and health regulations in Nigeria: An exploration. European Scientific Journal, 3, 93-104.

lii. Van der Smissen, B. (2007). Elements of negligence. In D. J. Cotten \& J. T. Wolohan (Eds.) Law for recreation and sport managers (4th Ed.). Dubuque, IA: Kendall Hunt. (pp. 36-45).

liii. Van der Smissen, B. (2007). Elements of negligence. Law for recreation and sport managers, 36-45.

liv. Waddington, I., \& Smith, A. (2013). Sport, health and drugs: A critical sociological perspective. Routledge. 